\title{
Internalized stigma in physicians with mental illness
}

\author{
Ruhsal bozukluk tanısı olan hekimlerde içselleştirilmiş damgalanma
}

\author{
Oğuzhan Kılınçel1, Rukiye Ay² \\ ${ }^{1}$ Assis. Prof., Istanbul Gelisim University, Department of Child Development, Istanbul, Turkey https://orcid.org/0000-0003-2988-4631 \\ 2M.D, Bursa Yüksek Ihtisas Training and Research Hospital, Department of Psychiatry, Bursa, Turkey https://orcid.org/0000-0003-2854-5128
}

\section{SUMMARY}

Objective: Internalized stigma means accepting negative statements and stereotypes about the disorder in people with mental disorders and reflecting on their thoughts and behaviors. High levels of internalized stigma negatively affect the recovery process in mental disorders and reduce functionality. In our study, it is aimed to determine the internal stigmatization levels of physicians with mental disorders and the factors affecting stigmatization levels. Method: The study was conducted between October 1, 2020-November 30, 2020, using an online cross-sectional self-report survey, and included 156 volunteer physicians who completed the survey questions. A "sociodemographic and clinical characteristics evaluation form" and the "Internalized Stigma of Mental Illness Scale" were applied to all participants. Results: It was observed that physicians were most frequently diagnosed with Major Depressive Disorder $(54.5 \%)$ and Anxiety Disorder (32.1\%). It was observed that $62.8 \%$ of physicians used psychopharmacological treatment, $12.8 \%$ had attempted suicide, and $8.3 \%$ received inpatient treatment. There was no statistical difference between the age, gender, professional experience, and departments of the groups considered as high- and low-internalized stigma. Individuals with Bipolar Disorder, ADHD, and Substance Use Disorder were observed to be in the high internal stigma group. In addition, a higher rate of family history of psychiatric illness was observed in the high-internalized stigma group. Discussion: Our study demonstrated that physicians with a mental illness had internalized stigma as in individuals with mental illness. Considering that internalized stigma affects attitudes and behaviors towards these patients, determining these differences will be a guide in struggles to prevent stigma against mental illnesses.

Key Words: Mental illnesses, internalized stigma, physicians

(Turkish J Clinical Psychiatry 2021;24:459-466)

\section{ÖZET}

Amaç: i̇çselleştirilmiş damgalanma, ruhsal bozukluğu olan kişilerde bozuklukla ilgili olumsuz söylemleri ve stereotipleri kabul etmesi ve düşünce ve davranışlarına yansıtması anlamına gelmektedir. Yüksek içselleştirilmiş damgalanma düzeyleri, ruhsal bozukluklarda sağlatım sürecini olumsuz etkilemektedir ve işlevselliği düşürmektedir. Çalışmamızda ruhsal bozukluklara sahip hekimlerin içsel damgalanma düzeylerini ve bu düzeylere etki eden faktörlerin belirlenmesi amaçlanmaktadır. Yöntem: 1 Ekim 2020-30 Kasım 2020 tarihleri arasında çevrimiçi kesitsel öz bildirim anketi kullanılarak yapılmıştır ve Anket sorularını tamamlayan 156 gönüllü hekim çalışmaya dahil edildi. Tüm katılımcılara 'Sosyodemografik ve klinik özellikler değerlendirme formu' ve "Ruhsal hastalıklarda içselleştirilmiş damgalanma ölçeği" uygulanmıştır. Bulgular: Hekimlerin en sık oranda Major Depresif Bozukluk $(\% 54,5)$ ve Anksiyete Bozukluğu $(\% 32,1)$ tanılarının olduğu gözlendi. Hekimlerin \%62,8'sinin psikofarmakolojik tedavi kullandığı, \%12,8'inin intihar girişimi olduğu ve \%8,3'ünün yatarak tedavi gördüğü gözlendi. Yüksek ve düşük içsel damgalanma olarak kabul edilen grupların yaş, cinsiyet, mesleki tecrübe ve bölümleri arasında istatistiksel fark saptanmamıştır. Bipolar Bozukluk, DEHB ve Madde Kullanım Bozukluğu olan bireylerin daha yüksek oranlarda yüksek içsel damgalanma grubunda olduğu gözlenmiştir. Ayrıca yüksek içsel damgalanma grubunda ailede psikiyatrik hastalık öyküsünün daha yüksek oranda olduğu gözlendi. Sonuç: Çalışmamızda ruhsal hastalığa sahip bireylerde olduğu gibi ruhsal bir hastalığa sahip hekimlerde de içselleştirilmiş damgalanmanın olduğu gösterilmiştir. İçselleştirilmiş damgalanmanın, bu hastalara yönelik tutum ve davranışları etkilediği göz önüne alındığında bu farklılıkların belirlenmesinin ruhsal hastalıklara yönelik damgalanmayı önlemeye yönelik yapılan mücadelelerde yol gösterici olacaktır.

Anahtar Sözcükler: Ruhsal hastalık, içsel damgalanma, hekimler 


\section{INTRODUCTION}

Stigma is defined as disgracing, devaluing, and disparaging an individual in a way to distinguish $\mathrm{him} / \mathrm{her}$ from other individuals in society. It occurs when the values of an individual and the values accepted by the society lived in do not match (1). Unfortunately, stigmatization, discrimination or exclusion for mental illnesses are common in many societies, although their severity varies. The most important determinants of stigma are the norms and characteristics of the culture lived in. Other factors include different belief systems, cultures, mental and historical reasons, descriptive characteristics such as age, gender, educational level, profession, marital status, socioeconomic status, level of knowledge of the disease, mental illness perception and label, characteristics of the disease, poor prognosis and mass communication tools (2).

Among the many types of stigma, the internalized stigma causes the greatest harm to the individual (3). Internalized stigma begins with the perception of stigma that rises in individual's mind when $\mathrm{s} / \mathrm{he}$ needs help. The most important source of stigma perception is the individual himself/herself. The perception of stigma emerges when an individuals is diagnosed with a mental illness and starts to think that many people will also refuse and devalue $\mathrm{him} / \mathrm{her}$ in the direction of his/her own perceptions, independent of concrete stigma and exclusion experiences (4). While individuals are trying to cope with the symptoms caused by mental disorders on the one hand, on the other hand, they are labeled due to their mental disorders and may be exposed to discrimination, negative emotional reactions, and prejudices of the society. As a result of all these factors, the individual accepts the negative judgments of the society about himself/herself and begins to withdraw himself/herself from the society due to negative feelings and thoughts such as worthlessness and shame (5). They often live alone and in isolation from society (6).

In mental illnesses, the length of hospital stay, the prolongation of the illness, the increase in the severity of the illness, the high level of disability and receiving electroconvulsive therapy (ECT) increase the level of internalized stigma. In addition, the perception of stigma is higher in patients who have impaired social and professional skills due to an illness compared to the past (7). On the other hand, it is known that patients who have more information about their illness and post-illness treatment have a lower perception of stigma (2).

Physicians are much more likely to encounter individuals with mental illness due to their profession in almost all fields of medicine. For this reason, their thoughts about mental illnesses and people with mental illnesses significantly affect their approach, attitude and behavior towards these patients(8). When the literature is reviewed, it is notable that the majority of studies focus on the attitudes of psychiatrists, general practitioners, non-psychiatric specialists, medical school students, nurses and nursing students. On the other hand, there are a limited number of studies on internalized stigma and perception of stigma, which is one of the important factors affecting the attitudes of health professionals.

Our study aimed to determine the internalized stigma levels of physicians with similar diseases, who have a profession more likely to encounter individuals with mental illnesses, and the influencing factors.

\section{METHODS}

\section{Universe of the Study}

This study was conducted between October 1, 2020 and November 30, 2020, using an online cross-sectional self-report survey.The universe of the study consisted of physicians working in 27 different medical specialties. The sampling was determined using the easy sampling and snowball method according to the accessibility-availability principle. The data were obtained via Google Forms surveys and mail. The study included 156 volunteer physicians who completed the survey questions.

\section{Data Collection Tools}

1. Sociodemographic and clinical characteristics evaluation form: It wasprepared by the researchers. It questions the physicians' age, gender, marital sta- 
tus, professional experience, and knowledge of psychiatric disorders. It includes clinical information such as diagnosis of the illness, duration of illness, treatments used, family history of psychiatric illness, hospitalization and suicide.

\section{Internalized Stigma of Mental Illness (ISMI) Scale:} It was developed by Ritsher et al. to evaluate internal stigma in mental illnesses, (9) and the Turkish validity and reliability study of the scale was performed by Ersoy and Varan (10). ISMI is a fourpoint Likert-type self-report scale consisting of 29 items. The scale has five subscales: Alienation, Stereotype Endorsement, Perceived Discrimination, Social Withdrawal, and Stigma Resistance(10).

Alienation (6 items): This subscale aims to measure the subjective experience of the individual such as being ashamed of his/her illness, feeling like a stranger and not understood in society, feeling inferior to other people due to his/her illness, and dissatisfaction with himself/herself.

Stereotype Endorsement (7 items): This subscale aims to measure the extent to which an individual agrees with the stereotypes of society related to individuals with mental illness. This section questions stereotypes such as people with mental illness are violent, they should not get married, they cannot live a good, satisfying life, mental illnesses can be noticed when looking from outside, people with mental illness cannot decide on their own, they need help, they do not contribute to society, and society's negative judgments about my illness.

Perceived Discrimination (5 items): It aims to determine the perceptions the individual is discriminated by others due to his/her illness, they are often told what to do, they are ignored or not taken seriously, other people hesitate to get close, and they will not be successful.

Social Withdrawal (6 items): It aims to evaluate the thoughts that prevent the person from interacting with other people. Conditions such as not being afraid of rejection, not being socialized because of thinking that $\mathrm{s} / \mathrm{he}$ looks weird, avoiding talking about himself/herself because of thinking that other people will be bored, not feeling belonging to the environment while being with other people, staying away from social environments because of being afraid of embarrassing his/her family and friends are evaluated.

Stigma Resistance (5 items): It aims to measure the experience of being affected by internalized stigma. As the individual's stigma resistance score increases, the level of being affected by stigma increases. Here, it is used to measure the thoughts that people with mental illness cannot contribute to society, being seen with someone with a mental illness will bother, living does not make a struggling individual, the individual does not live his/her life as $\mathrm{s} / \mathrm{he}$ wishes, and the individual does not have a good and satisfying life due to his/her mental illness. The items of this subscale are reverse scored. A high ISMI score means that the individual negatively experiences a higher level of internalized stigma.

The total ISMI score obtained by summing the scores of the five subscales ranges between 29 and 116 points, with an average score ranging between 1-4 points. A score of 2 points or less on ISMI indicates a minimum level of stigma, a score of 2-2.49 points indicates mild, a score between 2.5 and 3 points indicates a severe level of internal stigma experienced. In the validity and reliability study of the scale, the internal consistency coefficient obtained for the whole scale was.93, if the the splithalf reliability of the scale was.89 (10).

\section{Statistical Analysis}

The study data were uploaded to the computer environment with SPSS version 21 (Chicago, IL). Descriptive statistics were presented as median (Q1-Q3), frequency distribution, and percentage for non-parametric evaluations. Group comparisons were performed using Fisher's exact test and the chi-squared tests. The level of statistical significance was set $\mathrm{p}<0.05$.

Ethical Approval: The study was approved by the Non-Invasive Trial Ethics Committee of Sakarya University with the date of 22/09/2020 and the number of 71522473/050.01.04/512. 
Kılıncel O, Ay R.

Table 1. Sociodemographic data of the study group

\begin{tabular}{llcc}
\hline Study parameters & & \% & (n:156) \\
\hline Age & $18-35$ & 46.2 & 72 \\
& $36-45$ & 42.9 & 67 \\
& $46-55$ & 9.6 & 15 \\
& $>55$ & 1.3 & 5 \\
\hline Gender & Male & 9.0 & 14 \\
& Female & 91.0 & 142 \\
\hline Professional experience & $1-10$ & 49.4 & 77 \\
& $11-20$ & 39.7 & 62 \\
& $21-30$ & 9.6 & 15 \\
& $>30$ & 1.3 & 2 \\
\hline Department & General practitioner & 17.9 & 28 \\
& Family medicine & 12.2 & 19 \\
& Pediatrics & 10.9 & 17 \\
& Psychiatry & 10.9 & 17 \\
& Emergency medicine & 6.4 & 10 \\
& Anesthesia & 5.1 & 8 \\
& Internal medicine & 4.5 & 7 \\
& Infectious diseases & 4.5 & 7 \\
\hline
\end{tabular}

\section{RESULTS}

The data of 156 physicians from 27 different medical specialties were analyzed in our study. It was observed that most of the physicians participating in the study were female $(91.0 \%)$ and were between $18-35$ years of age $(46.2 \%)$. The sociodemographic data of the study group are shown in Table 1.

The analysis of the clinical data showed that physicians were most frequently diagnosed with Major Depressive Disorder (54.5\%) and Anxiety Disorder $(32.1 \%), 62.8 \%$ used psychopharmacological therapy, $12.8 \%$ had suicide attempt, and $8.3 \%$ received inpatient treatment. Table 2 shows the clinical data of the study group.

The analysis of the study group data on internalized stigma showed that the highest scores were obtained from the alienation and stereotype endorsement subscales. Table 3 shows the data on internalized stigma.

The analysis of the data on total stigma showed that there were 35 physicians above the Q3 level and were recorded as the high-internalized stigma group. There was no statistical difference between the age, gender, professional experience and departments of the groups considered as high- and low-internalized stigma. Table 4 shows the comparison of the sociodemographic data of the participants with high- and low-internalized stigma.

The comparison of the clinical data of the participants with high- and low-internalized stigma showed that a higher proportion of individuals with Bipolar Disorder, ADHD and Substance Use Disorder were in the high-internalized stigma group. In addition, a higher rate of family history of

Table 2. Clinical data of the study group

\begin{tabular}{llll}
\hline Study Parameter & \% & (n:156) \\
\hline Psychiatric & Major Depressive Disorder & 54.5 & 85 \\
diagnosis & Anxiety Disorder & 32.1 & 50 \\
& Obsessive Compulsive Disorder & 5.8 & 9 \\
& Bipolar Disorder & 3.2 & 5 \\
& Attention Deficit Hyperactivity Disorder & 2.6 & 4 \\
& Substance Use Disorder & 1.3 & 2 \\
& Psychotic Disorder & 0.6 & 1 \\
\hline Disease & $0-1$ & 11.5 & 18 \\
Duration & $2-10$ & 63.5 & 99 \\
& $11-20$ & 17.3 & 27 \\
& $>20$ & 7.7 & 12 \\
\hline Family history of psychiatric illness & 62.8 & 98 \\
\hline Suicide attempt & 59.0 & 92 \\
\hline Inpatient treatment & 12.8 & 20 \\
\hline 462 & 8.3 & 13 \\
\end{tabular}


Table 3. Data on internalized stigma

\begin{tabular}{l|l|l}
\hline Study Parameter & Median & Q1-Q3 \\
\hline Alienation & 13 & $10-16$ \\
\hline Stereotype endorsement & 12 & $9-15$ \\
\hline Perceived discrimination & 8 & $6-11$ \\
\hline Social Withdrawal & 11 & $8-14$ \\
\hline Stigma resistance & 7 & $5-8$ \\
\hline Total internalized stigma & 49 & $38-61$ \\
\hline
\end{tabular}

psychiatric illness was observed in the high-internalized stigma group. Table 4 shows the comparison of the clinical data of the participants with high- and low-internalized stigma.

\section{DISCUSSION}

Our study included 156 physicians from 27 different departments, most of whom consisted of general practitioners. Most of the physicians participated in the study were female and were between the ages of 18-35 years. It was observed that the most common diagnoses of the physicians were Major Depressive Disorder and Anxiety Disorder.

Considering the data of the physicians on internal stigma, it was observed that the highest scores were obtained from the alienation and stereotype endorsement subscales. A study by the Mood Disorders Scientific Unit of the Psychiatric Association of Turkey reported that $46 \%$ of patients felt themselves complete, partially inadequate or incomplete, and $40 \%$ were perceived by those around them as complete, partially inade- quate or incomplete. In the same study, it was stated that $60 \%$ of patients thought that their illness would negatively affect marriage, and $55 \%$ of patients thought that their illness might cause them to have difficulty in finding a job (10).

When the study population was grouped based on having high- and low-internalized stigma, there was no significant difference between the groups in terms of age, gender, professional experience, and their departments. Most sociodemographic characteristics are believed to have no significant effect on internalized stigma (11). Studies have reported conflicting results on the effects of age. Some studies have shown that younger patients experience less stigma, suggesting that this is related to the more tolerant of young individuals. Some studies have reported that young individuals have a higher perception of stigma. A study conducted in Turkey showed that an early onset of illness increased the perception of stigma (2).

It has been shown in the literature that the perception of stigma is higher in patients who cannot return to their previous functionality after illness (12). According to many authors, patients cannot take or avoid taking their former roles both socially and professionally due to the perception of stigma regardless of their symptoms, even if they are in

Table 4. Comparison of the sociodemographic data of the participants with high- and low-internalized stigma

\begin{tabular}{|c|c|c|c|c|c|}
\hline \multicolumn{2}{|c|}{ Study Parameter } & $\begin{array}{l}\text { Low-internalized } \\
\text { stigma } \\
(\mathrm{n}: 121)\end{array}$ & $\begin{array}{l}\text { High-internalized } \\
\text { stigma } \\
(\mathrm{n}: 35)\end{array}$ & Statistics & p \\
\hline \multirow[t]{4}{*}{ Age } & $18-35$ & $45.5 \%(\mathrm{n}: 55)$ & $48.6 \%$ (n:17) & $2.639^{*}$ & 0.475 \\
\hline & $36-45$ & $41.3 \%(\mathrm{n}: 50)$ & $48.6 \%(\mathrm{n}: 17)$ & & \\
\hline & $46-55$ & $11.6 \%(\mathrm{n}: 14)$ & $2.9 \%(\mathrm{n}: 1)$ & & \\
\hline & $>55$ & $1.7 \%(\mathrm{n}: 2)$ & $0.0 \%(\mathrm{n}: 0)$ & & \\
\hline \multirow[t]{2}{*}{ Gender } & Male & $9.1 \%(\mathrm{n}: 11)$ & $8.6 \%(\mathrm{n}: 3)$ & $1.000^{*}$ & 0.614 \\
\hline & Female & $90.9 \%(\mathrm{n}: 110)$ & $91.4 \%(\mathrm{n}: 32)$ & & \\
\hline \multirow{4}{*}{$\begin{array}{l}\text { Professional } \\
\text { experience }\end{array}$} & $1-10$ & $47.1 \%(\mathrm{n}: 57)$ & $42.9 \%(\mathrm{n}: 15)$ & $5.870^{*}$ & 0.103 \\
\hline & $11-20$ & $38.8 \%(\mathrm{n}: 47)$ & $57.1 \%(\mathrm{n}: 20)$ & & \\
\hline & $21-30$ & $12.4 \%(\mathrm{n}: 159)$ & $0.0 \%(\mathrm{n}: 0)$ & & \\
\hline & $>30$ & $1.7 \%(\mathrm{n}: 2)$ & $0.0 \%(\mathrm{n}: 0)$ & & \\
\hline \multirow[t]{9}{*}{ Department } & General practitioner & $16.5 \%(\mathrm{n}: 20)$ & $22.9 \%(n: 8)$ & $10.283^{*}$ & 0.210 \\
\hline & Family medicine & $11.6 \%(\mathrm{n}: 14)$ & $14.3 \%(\mathrm{n}: 5)$ & & \\
\hline & Pediatrics & $12.4 \%(\mathrm{n}: 15)$ & $5.7 \%(\mathrm{n}: 2)$ & & \\
\hline & Psychiatry & $12.4 \%(\mathrm{n}: 15)$ & $5.7 \%(\mathrm{n}: 2)$ & & \\
\hline & Emergency medicine & $7.4 \%(\mathrm{n}: 9)$ & $2.9 \%(\mathrm{n}: 1)$ & & \\
\hline & Anesthesia & $4.5 \%(\mathrm{n}: 6)$ & $5.7 \%(\mathrm{n}: 2)$ & & \\
\hline & Internal medicine & $5.8 \%(\mathrm{n}: 7)$ & $0.0 \%(\mathrm{n}: 0)$ & & \\
\hline & Infectious Diseases & $5.8 \%(\mathrm{n}: 7)$ & $0.0 \%(\mathrm{n}: 0)$ & & \\
\hline & Other & $23.1 \%(\mathrm{n}: 28)$ & $42.9 \%(\mathrm{n}: 15)$ & & \\
\hline
\end{tabular}

Note: * Fisher's exact test was used. 
Kılıncel O, Ay R.

\begin{tabular}{|c|c|c|c|c|c|}
\hline \multicolumn{2}{|l|}{ Study Parameter } & $\begin{array}{l}\text { Low-internalized } \\
\text { stigma } \\
\text { (n:121) }\end{array}$ & $\begin{array}{l}\text { High-internalized } \\
\text { stigma } \\
(\mathbf{n}: 35)\end{array}$ & $\begin{array}{l}\text { Statistics } \\
31.717^{*}\end{array}$ & $\begin{array}{l}p \\
0.001\end{array}$ \\
\hline $\begin{array}{l}\text { Psychiatric } \\
\text { disorder }\end{array}$ & $\begin{array}{l}\text { Major Depressive Disorder } \\
\text { Anxiety Disorder } \\
\text { OCD } \\
\text { Bipolar Disorder } \\
\text { ADHD } \\
\text { Substance Use Disorder } \\
\text { Psychotic Disorder }\end{array}$ & $\begin{array}{l}52.9 \%(\mathrm{n}: 64)^{\mathrm{a}} \\
39.7 \%(\mathrm{n}: 48)^{\mathrm{a}} \\
5.0 \%(\mathrm{n}: 6)^{\mathrm{a}} \\
0.8 \%(\mathrm{n}: 1)^{\mathrm{a}} \\
0.8 \%(\mathrm{n}: 1)^{\mathrm{a}} \\
0.0 \%(\mathrm{n}: 0)^{\mathrm{a}} \\
0.8 \%(\mathrm{n}: 1)^{\mathrm{a}} \\
\end{array}$ & $\begin{array}{l}60.0 \%(\mathrm{n}: 21)^{\mathrm{a}} \\
5.7 \%(\mathrm{n}: 2)^{\mathrm{b}} \\
8.6 \%(\mathrm{n}: 3)^{\mathrm{a}} \\
11.4 \%(\mathrm{n}: 4)^{\mathrm{b}} \\
8.6 \%(\mathrm{n}: 3)^{\mathrm{b}} \\
5.7 \%(\mathrm{n}: 2)^{\mathrm{b}} \\
0.0 \%(\mathrm{n}: 0)^{\mathrm{a}} \\
\end{array}$ & $31.717 *$ & 0.001 \\
\hline Disease Duration & $\begin{array}{l}0-1 \\
2-10 \\
11-20 \\
>20\end{array}$ & $\begin{array}{l}13.2 \%(\mathrm{n}: 16) \\
65.3 \%(\mathrm{n}: 79) \\
14.9 \%(\mathrm{n}: 18) \\
6.6 \%(\mathrm{n}: 8)\end{array}$ & $\begin{array}{l}5.7 \%(\mathrm{n}: 2) \\
57.1 \%(\mathrm{n}: 20) \\
25.7 \%(\mathrm{n}: 9) \\
11.4 \%(\mathrm{n}: 4)\end{array}$ & $4.265^{*}$ & 0.233 \\
\hline \multicolumn{2}{|c|}{ Psychopharmacological therapy } & $35.5 \%(\mathrm{n}: 43)$ & $42.9 \%(\mathrm{n}: 15)$ & & \\
\hline \multicolumn{2}{|c|}{ Family history of psychiatric illness } & $54.5 \%(\mathrm{n}: 65)$ & $74.3 \%(\mathrm{n}: 27)$ & $6.156 * *$ & 0.013 \\
\hline \multicolumn{2}{|l|}{ Suicide attempt } & $11.6 \%(\mathrm{n}: 14)$ & $17.1 \%(\mathrm{n}: 6)$ & $0.396 * *$ & 0.272 \\
\hline \multicolumn{2}{|l|}{ Inpatient treatment } & $7.4 \%(\mathrm{n}: 9)$ & $11.4 \%(\mathrm{n}: 4)$ & $0.490 *$ & 0.327 \\
\hline
\end{tabular}

Note: ${ }^{\text {a, }}$ The same letters show that there is no difference between the columns. *Fisher's exact test was used. **The ekiquared test was used.

remission (13). It is seen that these two situations turn into a vicious cycle, affecting each other. The physicians that make up the study group are still actively working. The fact that they are still serving as physicians and taking part in work life suggests that they have broken the vicious cycle and prevented patients from staying away from the society. Though our results were not statistically significant, there were more individuals in the low-internalized stigma group. It has been reported that patients who are more knowledgeable about their illness, characteristics, and treatments have a lower perception of stigma (2). For this reason, it is believed that the reason for the absence of a significant difference between departments is that physicians have attended at least one training or seminar on mental illnesses in some part of their medical education and expertise.

Individuals with Anxiety Disorder, Bipolar Disorder, ADHD and Substance Use Disorder as a diagnosis of mental illness were observed to be in the high-internalized stigma group. A study conducted abroad investigating the internalized stigma levels of 280 patients diagnosed with Schizophrenia, Depression, Anxiety and OCD showed that $43.6 \%$ of all patients had a high rate of internalized stigma and that $34 \%$ of schizophrenia patients, $21 \%$ of anxiety disorder patients, $38 \%$ of depression patients, and 29\% of OCD patients had a higher level of internalized stigma (14). Stigma perception begins with the patient's diagnosis. Receiving a diagnosis creates a sense of labeling in patients. The label of a mental illness is usually suf- ficient alone to experience the feeling of stigma. In addition, the type of psychopathology affects the level of perception of stigma regardless of the label. The higher the stigma content of the diagnosis, the greater the stigma perception of patients (15). Studies have shown that patients diagnosed with substance use disorder have a higher perception of stigma than other patient groups (16). Diseases requiring continuous use of drugs, especially in patients diagnosed with schizophrenia and bipolar disorder, have been shown to increase the perception of stigma (17). The necessaity of continuous drug use disrupts the adaptation process of patients. Studies have shown that the disruption of adherence to medication is due to fear of internal stigma rather than drug-related side effects (18). A study found that the internalized stigma scores of bipolar patients who did not work and who irregularly used medication were higher (19). Another study conducted on patients diagnosed with bipolar disorder reported that patients had thoughts that they would not be accepted as friends by the society, they would be considered less intelligent and unreliable, employers would not pay them enough and would not behave as they did to other employees, and their opinions would be taken less seriously because they were hospitalized in a psychiatric clinic (20).

It was found that the family history of psychiatric illness was higher in the physicians in the highinternalized stigma group. One of the important factors determining the feeling of stigma is the person's immediate environment. Internalized stigma 
is also activated in the individual's immediate environment, and as a result, people in the patient's immediate surroundings experience the perception of stigma and stigmatize and exclude the patient (21). Some studies have reported that the patient relatives feel ashamed of the presence of an individual with mental illness in their family and try to hide this (22). With all these processes, the stigma perception of the patient, who is already sensitive to stigmatization, increases more.

\section{Limitations of the study}

Our study has some limitations. In general, the feeling of internal stigma is experienced more in individuals with more severe mental illness and in people with more severe form of the same mental illness. In our study, the level of internal stigma was evaluated only at the diagnostic level, and its severity was not examined. It is notable that the majority of studies on internalized stigma in the literature are conducted on a specific disease. Some differences between our results and the literature may be due to this limitation of our study. In addition, it is known that the level of mental disorder and the disease duration are associated with the level of stigma perception, the greater disability and the longer disease duration causes the individual to feel a higher level of stigma. When we look at the physicians participated in our study, the small number of individuals with long disease duration may have affected our results.

\section{CONCLUSION}

Despite all these limitations, we obtained valuable data on the presence of internalized stigma in physicians with a mental illness as with individuals with mental illness. Considering that internalized stigma affects attitudes and behaviors towards these patients, interventions for internalized stigma in physicians with mental illness can provide significant progress in strengthening the mental health of both the individual and the community they provide healthcare services.

Conflict of Interest: The authors declare that they have no conflict of interest
Correspondence address: Assis. Prof. Oguhan Kılıncel, Istanbul Gelisim University, Department of Child Development, Istanbul, Turkey okilincel@gmail.com 


\section{REFERENCES}

1. Goffman E. Stigma: Notes on the management of spoiled identity: Simon and Schuster; 2009.

2. Taşkın EO. İçselleştirilmiş damga ve damgalanma algısı. In: Taşkın EO, editor. Stigma Ruhsal Hastalıklara Yönelik Tutumlar ve Damgalama 1ed: Meta Basım ve Matbaacilı; 2007. p. 31-40.

3. Kök H, Demir S. Şizofreni ve bipolar bozukluğu olan hastalarda içselleștirilmis damgalanma, benlik saygısı ve algılanan sosyal destek. Cukurova Medical Journal. 2018;43(1):99-106.

4. Ritsher JB, Phelan JC. Internalized stigma predicts erosion of morale among psychiatric outpatients. Psychiatry research. 2004;129(3):257-65.

5. Corrigan PW. The impact of stigma on severe mental illness. Cognitive and behavioral practice. 1998;5(2):201-22.

6. Fırat M, Gökmen BD, Cengiz M. Orjinal Makale Psikiyatri servisinde yatan hastalarda içselleştirilmiş damgalanma ve yalnızlık ilişkisinin incelenmesi.

7. Yanos PT, Roe D, Lysaker PH. Narrative enhancement and cognitive therapy: a new group-based treatment for internalized stigma among persons with severe mental illness. International journal of group psychotherapy. 2011;61(4):576-95.

8. Bağ B, Ekinci M. Sağlık personelinin ruhsal sorunları olan bireylere yönelik tutumlarının araştırılması. Elektronik Sosyal Bilimler Dergisi (elektronik). 2005;3(11):107-27.

9. Ritsher JB, Otilingam PG, Grajales M. Internalized stigma of mental illness: psychometric properties of a new measure. Psychiatry Res. 2003;121(1):31-49.

10. Ersoy MA, Varan A. Ruhsal hastalıklarda içselleştirilmiş damgalanma ölçeği Türkçe formu'nun güvenilirlik ve geçerlik çalışması. Türk Psikiyatri Dergisi. 2007;18(2):163-71.

11. Angermeyer MC, Matschinger H. The stigma of mental illness: effects of labelling on public attitudes towards people with mental disorder. Acta Psychiatr Scand. 2003;108(4):304-9.

12. Stuart H. Stigma and work. Healthc Pap. 2004;5(2):100-11.

13. Link BG, Phelan JC, Bresnahan M, Stueve A, Pescosolido BA. Public conceptions of mental illness: labels, causes, dangerousness, and social distance. Am J Public Health. 1999;89(9):1328-33.

14. Picco L, Pang S, Lau YW, Jeyagurunathan A, Satghare P, Abdin E, Vaingankar JA, Lim S, Poh CL, Chong SA, Subramaniam M. Internalized stigma among psychiatric outpatients: Associations with quality of life, functioning, hope and self-esteem. Psychiatry Res. 2016;246:500-6.

15. Dinos S, Stevens S, Serfaty M, Weich S, King M. Stigma: the feelings and experiences of 46 people with mental illness. Qualitative study. Br J Psychiatry. 2004;184:176-81.

16. Fortney J, Mukherjee S, Curran G, Fortney S, Han X, Booth BM. Factors associated with perceived stigma for alcohol use and treatment among at-risk drinkers. J Behav Health Serv Res. 2004;31(4):418-29.

17. Kocadere M. Bipolar bozukluğu olan hastaların ve gençlerin gözünden damgalanma. 10. Ulusal Sosyal Psikiyatri Kongresi, Ankara. 2003:49-50.
18. Perlick DA, Rosenheck RA, Clarkin JF, Sirey JA, Salahi J, Struening EL, Link BG. Stigma as a barrier to recovery: adverse effects of perceived stigma on social adaptation of persons diagnosed with bipolar affective disorder. Psychiatric services. 2001;52(12):1627-32.

19. Hançer NG, ÖzdemIr N, Şahin Ş. Bipolar bozukluğu olan evli kadın hastalarda içselleştirilmiş damgalanma düzeyinin evlilik uyumu ve aile içi süreçler ile ilişkisi. Anatolian Journal of Psychiatry. 2020;21(3).

20. Hayward P, Wong G, Bright JA, Lam D. Stigma and selfesteem in manic depression: an exploratory study. J Affect Disord. 2002;69(1-3):61-7.

21. Shibre T, Negash A, Kullgren G, Kebede D, Alem A, Fekadu A, Madhin G, Jacobsson L.. Perception of stigma among family members of individuals with schizophrenia and major affective disorders in rural Ethiopia. Social psychiatry and psychiatric epidemiology. 2001;36(6):299-303.

22. Polat A, Üçok A, Genç A, Aksüt D. Ruhsal hastalığı olan kişilerin ailelerinde stigma. 36. Ulusal Psikiyatri Kongresi, Antalya. 2000:339-40. 